\title{
PENGARUH KOMPENSASI BONUS, DEBT COVENANT DAN FIRM SIZE TERHADAP EARNING MANAGEMENT PADA PERUSAHAAN MANUFAKTUR
}

\author{
${ }^{1}$ Esi Arianti \\ ${ }^{2}$ Rusli Amrul \\ ${ }^{3}$ Sigit Ary Wijayanto \\ ${ }^{123}$ Sekolah Tinggi Ilmu Ekonomi AMM Mataram \\ sigitaryw@gmail.com
}

\begin{abstract}
ABSTRAK
Penelitian ini bertujuan untuk memperoleh bukti empiris pengaruh kompensasi bonus, debt covenant dan firm size terhadap earning management pada perusahaan manufaktur yang terdaftar di Bursa Efek Indonesia dengan earning management sebagai variabel dependen, sedangkan kompensasi bonus, debt covenant dan firm size sebagai variabel independen. Kompensasi bonus diukur menggunakan dummy, debt covenant menggunakan leverage, dan firm size menggunakan total aset. Earning management diukur dengan discretionary accrual menggunakan model Jones dimodifikasi. Penelitian ini merupakan jenis penelitian asosiatif kuantitatif menggunakan data sekunder berupa laporan keuangan tahunan perusahaan periode 2016-2018. Populasi pada penelitian ini sebanyak 52 perusahaan. Berdasarkan metode purposive sampling, maka diperoleh sampel sebanyak 20 perusahaan dengan jumlah data observasi sebanyak 60 data selama periode 2016-2018. Teknik analisis menggunakan analisis regresi linier berganda. Hasil analisis secara parsial menunjukkan bahwa variabel yang memiliki pengaruh signifikan terhadap earning management adalah kompensasi bonus dan debt covenant, sedangkan firm size tidak memiliki pengaruh yang signifikan terhadap earning management. Selanjutnya, hasil analisis secara simultan menunjukkan bahwa kompensasi bonus, debt covenant dan firm size secara bersama-sama memiliki pengaruh yang signifikan terhadap earning management.
\end{abstract}

Kata Kunci : kompensasi bonus, debt covenant, firm size dan earning management

\begin{abstract}
This study aims to obtain empirical evidence about the influence of bonus compensation, debt covenant, and firm size on earning management in manufacturing companies listed on Indonesia Stock Exchange with earning management as dependent variable. While bonus compensation, debt covenant and firm size a independent variables. Bonus compensation measured by using dummy, debt covenant measured by using leverage, and firm size measured by using total asset. Earning management measured by discretionary accrual using modified Jones model. This research used quantitative asosiative research type by using secondary
\end{abstract}


data from financial statement and annual report of manufakturing companies in the period 2016-2018. The population in this study are 52 companies. Based on the determination of the sample using the purposive sampling methode, samples obtained as many as 20 companies by the number of observation data as much as 60 data derived from the company's total sample multiple by the periode 2016 to 2018. Data analysis in this study was performed by multiple linear regression analysis. The result of the partial analysis showed that the variable have a significant influence on earning management is bonus compensation and debt covenant. While, firm size has no significant influence on earning management. Furthermore, the result of simultaneous analysis showed that bonus compensation, debt covenant and firm size together has significant influence on earning management.

Keywords : bonus compensation, debt covenant, firm size, and earning management

\section{PENDAHULUAN}

Laporan keuangan merupakan alat utama para manajer untuk menunjukkan efektifitas pencapaian tujuan dan melaksanakan fungsi pertanggungjawaban dalam organisasi (Pujiati dan Arfan, 2013:122). Menurut PSAK No. 1 (Revisi 2013) tujuan laporan keuangan adalah menyediakan informasi mengenai posisi keuangan, kinerja keuangan dan arus kas entitas yang bermanfaat bagi sebagian besar kalangan pengguna laporan keuangan dalam pengambilan keputusan ekonomi. Salah satu parameter penting dalam laporan keuangan yang digunakan untuk mengukur kinerja manajemen adalah laba (Widyaningdyah, 2001:90). Informasi laba dapat digunakan investor sebagai indikator utama dalam mengukur kinerja, menilai earning power perusahaan dimasa yang akan datang, mengestimasi resiko investasi atau kredit dan pertanggungjawaban manajemen (Pujiati dan Arfan, 2013:123). Namun demikian, pihak manajemen cenderung mengelola laba dengan melakukan manipulasi laporan keuangan agar menunjukkan laba yang memuaskan meskipun tidak sesuai dengan kondisi perusahaan sebenarnya.

Manajemen termotivasi untuk memperlihatkan kinerja yang baik dalam menghasilkan nilai atau keuntungan maksimal bagi perusahaan sehingga manajemen cenderung memilih dan menerapkan metode akuntansi yang dapat memberikan informasi laba lebih baik (Prasetyo, 2011:2). Tindakan tersebut dilakukan dengan cara memilih kebijakan akuntansi tertentu, dinaikkan maupun diturunkannya laba sesuai dengan keinginannya yang dikenal dengan istilah earning management (manajemen laba) (Yulivia, dkk, 2015:2).

Manajemen laba adalah campur tangan manajemen dalam proses pelaporan keuangan eksternal dengan tujuan menguntungkan dirinya sendiri (Setiawati dan Na'im, 2000:424). Sedangkan menurut Sulistyanto (2018:6) manajemen laba adalah upaya manajemen mengintervensi atau mempengaruhi informasi-informasi dalam laporan keuangan dengan tujuan untuk mengelabui stakeholder (pemegang saham) 
yang ingin mengetahui kinerja dan kondisi perusahaan. Manajemen laba timbul sebagai dampak persoalan keagenan yaitu karena adanya perbedaan kepentingan dan asimetri informasi antara pemilik dan pengelola (Kusumawardani, 2016:81).

Manajemen laba dipengaruhi berbagai faktor diantaranya kompensasi bonus, debt covenant dan firm size. Kompensasi bonus merupakan hadiah uang yang relatif kecil yang diberikan kepada karyawan untuk pekerjaan atau upaya yang luar biasa dalam periode waktu yang cukup pendek (Yulivia, dkk, 2015:3). Umumnya tujuan perusahaan merancang sistem kompensasi bonus adalah untuk memotivasi, memikat dan mempertahankan karyawan yang kompeten serta mematuhi semua peraturan hukum (Elfira, 2014:12).

Beberapa penelitian terkait kompensasi bonus telah dilakukan oleh Elfira (2014), dan Yulivia, dkk (2015) menyatakan bahwa kompensasi bonus berpengaruh positif terhadap manajemen laba. Jika kompensasi bonus mengalami peningkatan, maka tindakan manajemen laba juga meningkat. Hal ini bertentangan dengan penelitian yang dilakukan oleh Prasetyo (2011) yang menyatakan bahwa kompensasi bonus berpengaruh negatif terhadap manajemen laba.

Debt covenant (perjanjian hutang) merupakan perjanjian untuk melindungi pemberi pinjaman dari tindakan-tindakan manajer terhadap kepentingannya (Pambudi, 2017:89). Perjanjian hutang dilakukan untuk menjamin manajemen akan melakukan aktivitas-aktivitas ekonomi yang mengarah pada upaya mengembalikan pinjaman yang diberikan tepat pada waktunya (Indra, 2016:5).

Penelitian terkait perjanjian hutang telah dilakukan oleh Yupita, et al (2017) menyatakan bahwa perjanjian hutang berpengaruh signifikan terhadap manajemen laba. Namun hasil penelitian ini berbeda dengan penelitian yang dilakukan oleh Prasetyo (2011) yang menyatakan bahwa perjanjian hutang tidak memiliki pengaruh yang signifikan terhadap manajemen laba.

Firm size (ukuran perusahaan) merupakan nilai yang menunjukan besar kecilnya perusahaan. Pengukuran perusahaan bertujuan untuk membedakan secara kuantitatif antara large firm dengan small firm dikarenakan besar kecilnya suatu perusahaan dapat mempengaruhi kemampuan manajemen untuk mengoperasikan perusahaan dengan berbagai situasi dan kondisi yang dihadapinya (Yulia, 2013:7).

Penelitian terkait ukuran perusahaan telah dilakukan oleh Prasetyo (2011) dan Widowati (2013) menyatakan bahwa ukuran perusahaan berpengaruh positif terhadap manajemen laba, berbeda dengan penelitian Gunawan, dkk (2016) menyatakan bahwa ukuran perusahaan tidak berpengaruh signifikan terhadap manajemen laba.

Perusahaan manufaktur sektor industri barang konsumsi dipilih sebagai obyek dalam penelitian ini dikarenakan perusahaan ini sangat tahan terhadap segala kondisi ekonomi, karena produk yang dihasilkan merupakan produk dalam kategori primer dan selalu dibutuhkan kapan saja oleh masyarakat (Kusumawardani, 2016:80).

Penelitian ini bertujuan untuk memperoleh bukti empiris pengaruh kompensasi bonus, debt covenant, firm size terhadap earning management pada perusahaan manufaktur yang terdaftar di Bursa Efek Indonesia tahun 2016-2018. 


\section{TINJAUAN PUSTAKA}

\section{Agency Theory (Teori Agensi)}

Teori ini menjelaskan tentang adanya hubungan kontraktual antara dua pihak atau lebih yang salah satu pihak di sebut principal (prinsipal) yang menyewa pihak lain yang di sebut agent (agen) untuk melakukan beberapa jasa atas nama pemilik yang meliputi pendelegasian wewenang (Jensen \& Meckling, 1976:5).

Teori agensi memiliki asumsi bahwa masing-masing individu semata-mata termotivasi oleh kepentingan dirinya sendiri sehingga menimbulkan konflik kepentingan antara prinsipal dan agen (Tanomi, 2012:30). Pihak prinsipal termotivasi mengadakan perjanjian untuk menyejahterakan dirinya dengan profitabilitas yang selalu meningkat, sedangkan agen termotivasi untuk memaksimalkan pemenuhan kebutuhan ekonomi dan psikologisnya, antara lain dalam hal memperoleh investasi, pinjaman, maupun kontrak kompensasi (Widyaningdyah, 2001:91).

\section{Earning Management (Manajemen Laba)}

Praktek manajemen laba secara umum didefinisikan sebagai upaya manajer mengintervensi atau mempengaruhi informasi-informasi dalam laporan keuangan dengan suatu tujuan mengelabui stakeholder yang ingin mengetahui kinerja dan kondisi perusahaan (Sulistyanto, 2018:6). Menurut Scott (2009) dalam Yulivia, dkk (2015:2) manajemen laba merupakan keputusan manajer untuk memilih kebijakan akuntansi tertentu yang dianggap dapat membantu mencapai tujuan yang diinginkan baik untuk meningkatkan laba atau mengurangi kerugian yang dilaporkan.

Pola manajemen laba menurut Sulistyanto (2018:177) dapat dilakukan dengan cara antara lain:

1. Income increasing (penaikkan laba)

Upaya perusahaan mengatur agar laba periode berjalan menjadi lebih inggi dari laba sebenarnya.

2. Income decreasing (penurunan laba)

Upaya perusahaan mengatur agar laba periode berjalan menjadi lebih rendah dari laba sebenarnya.

3. Income smooting (perataan laba)

Upaya perusahaan mengatur labanya relatif sama selama beberapa periode.

\section{Kompensasi Bonus}

Menurut Randika (2012:10) kompensasi bonus merupakan imbalan berupa fisik maupun non fisik yang diterima karyawan atas hasil kerjanya sesuai dengan pengorbanan yang telah diberikannya pada organisasi atau perusahaan tempat ia bekerja. Sedangkan menurut Pujiningsih (2011:50) kompensasi bonus merupakan balas jasa yang diberikan oleh organisasi atau perusahaan kepada karyawan yang dapat bersifat finansial maupun non finansial pada periode yang tetap.

Dengan adanya kompensasi bonus, pihak manajemen akan berusaha meningkatkan profit atau laba perusahaan semaksimal mungkin agar laporan 
keuangan yang dihasilkan terlihat bagus, sehingga pihak manajemen akan mendapatkan bonus atas kerja kerasnya (Wijaya dan Christiawan, 2014:4).

Menurut Elfira (2014:7) terdapat beberapa faktor yang dapat mempengaruhi tingkat kompensasi bonus, antara lain :

1. Penawaran dan permintaan tenaga kerja

Jika pencari kerja (penawaran) lebih banyak daripada lowongan pekerjaan (permintaan), maka kompensasi relatif kecil, begitupun sebaliknya.

2. Kemampuan dan kesediaan perusahaan

Apabila kemampuan dan kesediaan perusahaan untuk membayar semakin baik, maka tingkat kompensasi akan semakin besar.

3. Serikat buruh/organisasi karyawan

Apabila serikat buruhnya kuat dan berpengaruh, maka tingkat kompensasi semakin besar.

4. Produktivitas kerja karyawan

Jika produktivitas kerja karyawan baik dan banyak, maka kompensasi akan semakin besar.

5. Pemerintah dengan Undang-Undang dan Keppres

Pemerintah dengan Undang-Undang dan Keppres menetapkan besarnya batas upah/balas jasa minimum.

\section{Debt Covenant (Perjanjian Hutang)}

Debt covenant merupakan perjanjian untuk melindungi pemberi pinjaman dari tindakan manajer terhadap kepentingan kreditor, seperti pinjaman tambahan, atau membiarkan modal kerja dan kekayaan pemilik berada dibawah tingkat yang telah ditentukan yang dapat menurunkan keamanan bagi kreditur yang telah ada (Nugroho, 2012:20). Bagi perusahaan yang mampu memenuhi perjanjian hutangnya akan mendapatkan penilaian kinerja yang baik dari kreditur (Herawati dan Baridwan, 2007:3). Sebaliknya, pelanggaran terhadap perjanjian hutang dapat mengakibatkan timbulnya suatu biaya serta dapat menghambat kerja manajemen, sehingga manajemen berusaha untuk mencegah atau setidaknya meminimalisir manajemen dalam melakukan income increasing (Fatmariani, 2013:7).

Menurut Janes (2003) dalam Herawati dan Baridwan (2007:3) perjanjian hutang dapat dikelompokkan ke dalam dua yaitu :

1. Perjanjian negatif umumnya menunjukkan aktivitas tertentu yang mengakibatkan subtitusi aset atau masalah pembayaran kembali.

2. Perjanjian positif mensyaratkan peminjam melakukan tindakan tertentu, seperti menjaminkan aset atau memenuhi benchmark tertentu yang mengindikasikan kesehatan keuangan.

\section{Firm Size (Ukuran Perusahaan)}

Firm size merupakan suatu skala dimana dapat diklasifikasikan dengan berbagai cara, antara lain total asset, log size, nilai pasar saham, dan lain-lain (Yulia, 2013:2). Untuk melakukan pengukuran terhadap ukuran perusahaan, total asset dapat 
menggambarkan ukuran perusahaan, semakin besar aset maka semakin besar perusahaan tersebut (Deviyanti dan Sudana, 2018:1424).

Ukuran perusahaan akan mempengaruhi struktur pendanaan perusahaan, dikarenakan kecendrungan perusahaan besar memerlukan dana yang lebih besar dibandingkan perusahaan yang lebih kecil, dan motivasi dalam memperoleh tambahan dana akan mendorong pihak manajemen untuk melakukan praktek manajemen laba, sehingga dengan pelaporan laba yang tinggi maka calon investor maupun kreditur akan tertarik untuk menanamkan dananya (Agustia, 2013:30).

Klasifikasi ukuran perusahaan menurut UU No. 20 Tahun 2008 Pasal 1 (satu) antara lain :

1. "Usaha mikro adalah usaha produktif milik orang perseorangan dan atau badan usaha perseorangan yang memenuhi kriteria usaha mikro sebagaimana diatur dalam undang-undang ini.

2. Usaha kecil adalah usaha produktif yang berdiri sendiri, yang dilakukan oleh orang perseorangan atau badan usaha yang bukan merupakan anak perusahaan atau cabang perusahaan yang dimiliki, dikuasai, atau menjadi bagian langsung maupun tidak langsung dari usaha menengah atau besar yang memenuhi kriteria usaha kecil sebagaimana dimaksud dalam undang-undang ini.

3. Usaha menengah adalah usaha ekonomi produktif yang berdiri sendiri, yang dilakukan oleh orang perseorangan atau badan usaha yang bukan merupakan anak perusahaan atau cabang perusahaan yang dimiliki, dikuasai, atau menjadi bagian baik langsung maupun tidak langsung dengan usaha kecil atau usaha besar dengan jumlah kekayaan bersih atau hasil penjualan tahunan sebagaimana diatur dalam undang-undang ini.

4. Usaha besar adalah usaha ekonomi produktif yang dilakukan oleh badan usaha dengan sejumlah kekayaan bersih atau hasil penjualan tahunan lebih besar dari usaha menengah, yang meliputi usaha nasional milik Negara atau swasta, usaha patungan, dan usaha asing yang melakukan kegiatan ekonomi di Indonesia".

\section{Hasil Penelitian Terdahulu}

Yupita, et al (2017) melakukan penelitian untuk mengetahui pengaruh baik secara parsial dan simultan bonus plans, debt to equity ratio, dan political cost terhadap manajemen laba pada perusahaan manufaktur sektor makanan dan minuman yang terdaftar di Bursa Efek Indonesia (BEI) periode 2012-2016. Hasil penelitian menunjukkan bahwa secara parsial dan simultan bonus plans, debt to equity ratio, dan political cost memiliki pengaruh yang signifikan terhadap manajemen laba.

Gunawan, dkk (2016) menganalisa pengaruh ukuran perusahaan, profitabilitas dan leverage terhadap manajemen laba pada perusahaan manufaktur yang terdaftar di Bursa Efek Indonesia (BEI). Hasil penelitian menunjukkan bahwa secara parsial maupun simultan ukuran perusahaan, profitabilitas dan leverage tidak memiliki pengaruh yang signifikan terhadap manajemen laba. 
Yulivia, dkk (2015) meneliti pengaruh kepemilikan institusional, kepemilikan publik, kompensasi bonus dan leverage terhadap manajemen laba pada perusahaan manufaktur di Bursa Efek Indonesia periode 2010-2014. Hasil penelitian menunjukkan bahwa kepemilikan institusional, kepemilikan publik dan leverage tidak memiliki pengaruh terhadap manajemen laba. sedangkan kompensasi bonus memiliki pengaruh terhadap manajemen laba.

Elfira (2014) menguji pengaruh kompensasi bonus dan leverage terhadap manajemen laba pada perusahaan manufaktur di BEI periode 2009-2012. Hasil penelitian menunjukkan bahwa kompensasi bonus memiliki pengaruh yang signifikan terhadap manajemen laba. leverage tidak memiliki pengaruh yang signifikan terhadap manajemen laba.

Widowati (2013) menguji pengaruh corporate governance, bonus plans dan firm size terhadap manajemen laba pada perusahaan industri semen di Bursa Efek Indonesia tahun 2007-2010. Analisis menunjukkan bahwa komite audit, bonus plans dan firm size memiliki pengaruh signifikan terhadap manajemen laba.

Prasetyo (2011) meneliti pengaruh corporate governance, bonus plans, debt covenant dan firm size terhadap manajemen laba pada perusahaan manufaktur di Bursa Efek Indonesia periode 2008-2010. Hasil analisis secara parsial menunjukkan bahwa firm size memiliki pengaruh signifikan terhadap manajemen laba. Selanjutnya, struktur dewan komisaris independen, komite audit, reputasi auditor, bonus plans, dan debt covenant tidak mempengaruhi manajemen laba secara signifikan.

\section{Rerangka Konseptual}
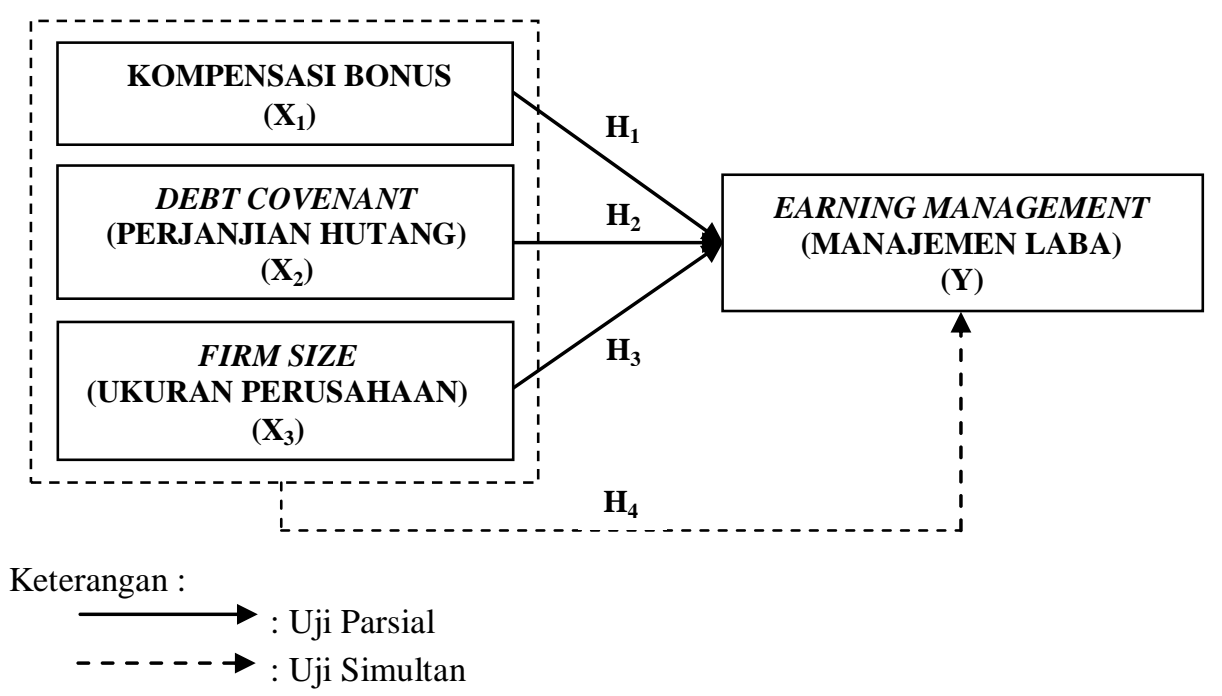

Gambar 1. Rerangka Konseptual 


\section{Pengaruh Signifikan Kompensasi Bonus Terhadap Earning Management}

Bonus plan hypothesis merupakan salah satu motif dalam pemilihan metode akuntansi yang tidak terlepas dari positif accounting theory (Prasetyo, 2011:35). Hipotesis ini menyatakan bahwa manajer dengan rencana bonus menyukai metode akuntansi yang dapat meningkatkan laba periode berjalan (Rindengan, 2015:2).

Jika perusahaan memiliki rencana bonus, maka manajer akan lebih cenderung melakukan tindakan mengatur laba untuk memaksimalkan bonus yang akan mereka terima (Pujiningsih, 2011:51). Elfira (2014:15) dalam penelitiannya menyatakan bahwa kompensasi bonus berpengaruh signifikan terhadap manajemen laba. Elfira (2014:16) juga menyatakan jika kompensasi bonus mengalami peningkatan, maka tindakan manajemen laba juga akan meningkat, begitupun sebaliknya. Sejalan dengan Yulivia, dkk (2015:11) yang menemukan adanya pengaruh kompensasi bonus terhadap manajemen laba yang membuat manajer memanipulasi laba untuk memaksimalkan bonus yang akan diterimanya. Berdasarkan penjelasan di atas, maka hipotesis dapat dirumuskan sebagai berikut:

$H_{1}$ : Kompensasi Bonus Berpengaruh Signifikan Terhadap Earning Management

\section{Pengaruh Signifikan Debt Covenant Terhadap Earning Management}

Debt covenant hypothesis menyatakan bahwa semakin dekat perusahaan dengan pelanggaran perjanjian hutang berbasis akuntansi, maka manajer akan cendrung memilih prosedur akuntansi yang dapat memindahkan laba yang dilaporkan dari periode mendatang ke periode berjalan, oleh karena itu manajer akan berusaha menghindari terjadinya pelanggaran terhadap hutang dengan mempengaruhi informasi akuntansi pada laporan keuangan dengan melakukan manajemen laba (Herawati dan Baridwan, 2007:4). Sejalan dengan penelitian Yupita, et al (2017:418) yang menyatakan bahwa perjanjian hutang berpengaruh positif dan signifikan terhadap manajemen laba. Semakin tinggi tingkat hutang maka semakin tinggi manajemen laba. Berdasarkan penjelasan di atas, maka hipotesis dapat dirumuskan sebagai berikut :

$\mathrm{H}_{2} \quad$ : Debt Covenant Berpengaruh Signifikan Terhadap Earning Management

\section{Pengaruh Signifikan Firm Size Terdahap Earning Management}

Ukuran perusahaan dianggap sebagai indikator yang menunjukkan tingkat kemampuan finansial dan tingkat resiko bagi investor yang dipercayai bahwa perusahaan memiliki kemampuan dalam menutupi segala kewajibannya dan memberikan tingkat pengembalian yang memadai bagi investor (Eddy, dkk, 2014:3).

Hasil penelitian yang dilakukan oleh Prasetyo (2011:24) dan Widowati (2013:50) menunjukkan bahwa ukuran perusahaan berpengaruh secara signifikan tehadap manajemen laba. Ukuran perusahaan memiliki hubungan dengan manajemen laba, semakin besar ukuran perusahaan, maka informasi yang tersedia untuk investor akan semakin banyak dalam pengambilan keputusan investasi (Pujiningsih, 2011:29). Berdasarkan penjelasan di atas, maka hipotesis dapat dirumuskan sebagai berikut :

$\mathrm{H}_{3} \quad$ : Firm Size Berpengaruh Signifikan Terhadap Earning Management 


\section{Pengaruh Signifikan Kompensasi Bonus, Debt Covenant, dan Firm Size Terdahap Earning Management}

Diindikasikan bahwa kompensasi bonus, perjanjian hutang, dan ukuran perusahaan secara bersama-sama memiliki pengaruh terdahap manajemen laba. Sejalan dengan penelitian yang dilakukan oleh Prasetyo (2011:24) menyatakan bahwa variabel independen dalam penelitian yaitu bonus plans, debt covenant dan firm size secara bersama-sama berpengaruh secara signifikan terhadap variabel dependen yaitu earning management (manajemen laba). Berdasarkan penjelasan di atas, maka hipotesis dapat dirumuskan sebagai berikut :

$\mathrm{H}_{4} \quad$ : Kompensasi Bonus, Debt Covenant dan Firm Size Berpengaruh Signifikan Terhadap Earning Management

\section{METODE PENELITIAN}

Teknik pengumpulan data yang digunakan dalam penelitian ini adalah teknik dokumentasi yaitu teknik pengumpulan data berupa catatan peristiwa baik dalam bentuk tulisan, gambar atau karya monumental yang dihasilkan oleh instansi yang berkaitan dengan penelitian (Sugiyono, 2014:240).

Populasi merupakan wilayah generalisasi yang terdiri atas obyek/subyek yang mempunyai kualitas dan karakteristik tertentu yang ditetapkan oleh peneliti untuk dipelajari dan kemudian ditarik kesimpulannya (Sugiyono, 2014:80). Populasi dalam penelitian ini adalah perusahaan manufaktur sektor industri barang konsumsi (consumer goods industry) yang terdaftar di Bursa Efek Indonesia (BEI) selama periode 2016-2018 yang berjumlah 52 perusahaan.

Sampel adalah bagian dari jumlah dan karakteristik yang dimiliki oleh populasi tersebut (Sugiyono, 2014:81). Teknik pengambilan sampel ditentukan menggunakan metode nonprobability sampling dengan teknik purposive sampling. Adapun kriterianya adalah :

1. Perusahaan manufaktur sektor industri barang konsumsi yang terdaftar di Bursa Efek Indonesia periode 2016-2018.

2. Perusahaan manufaktur sektor industri barang konsumsi yang tidak terdaftar secara berturut-turut di Bursa Efek Indonesia periode 2016-2018.

3. Perusahaan manufaktur sektor industri barang konsumsi yang mempublikasikan laporan keuangan tahunan yang telah diaudit secara rutin per 31 Desember di Bursa Efek Indonesia selama periode 2016-2018.

4. Perusahaan manufaktur sektor industri barang konsumsi yang baru terdaftar di Bursa Efek Indonesia (IPO) selama periode penelitian.

Berdasarkan kriteria di atas, diperoleh sampel sebanyak 20 perusahaan dengan jumlah observasi sebanyak 60 data perusahaan selama tiga tahun penelitian. 


\section{Jenis dan Sumber Data}

Jenis data yang digunakan adalah data kuantitatif. Data kuantitatif merupakan data yang berupa angka-angka (Sugiyono, 2014:7). Sumber data yang digunakan adalah data sekunder berupa data-data laporan keuangan tahunan perusahaan (annual report), khususnya laporan keuangan yang dipublikasikan oleh Bursa Efek Indonesia (BEI) melalui situs resminya www.idx.co.id. Data sekunder merupakan data yang diperoleh secara tidak langsung, yakni melalui media perantara yang berupa dokumen, catatan atau laporan historis yang dipublikasikan (Sugiyono, 2014:225).

\section{Identifikasi dan Definisi Operasional Variabel}

Berdasarkan identifikasi variabel, maka dapat diuraikan dari masing-masing variabel sehingga dapat dilakukan pengukuran sebagai berikut :

1. Kompensasi Bonus

Bonus plan hypothesis merupakan salah satu motif dalam pemilihan suatu metode akuntansi yang tidak terlepas dari positif acconting theory dimana hipotesis ini menyatakan bahwa manajer dengan rencana bonus lebih menyukai metode akuntansi yang dapat meningkatkan laba periode berjalan, jika perusahaan memiliki kompensasi, manajer akan cenderung melakukan tindakan mengatur laba bersih untuk dapat memaksimalkan bonus yang akan diterimanya (Palestin, 2008:6). Kompensasi bonus diukur menggunakan dummy dengan ketentuan nilai 1 untuk perusahaan yang memberikan bonus pada tahun tertentu, dan nilai 0 untuk perusahaan yang tidak memberikan bonus pada tahun tertentu (Prasetyo, 2011:40).

2. Debt Covenant (Perjanjian Hutang)

Debt covenant hypothesis menyatakan jika semakin dekat perusahaan dengan pelanggaran perjanjian hutang berbasis akuntansi, maka manajer memiliki kecendrungan memilih prosedur akuntansi yang dapat memindahkan laba yang dilaporkan dari periode mendatang ke periode berjalan, oleh karena itu manajer akan berusaha menghindari terjadinya pelanggaran dengan cara mempengaruhi informasi akuntansi pada laporan keuangan dengan melakukan manajemen laba (Herawati dan Baridwan, 2007:4). Dalam penelitian ini perjanjian hutang diproksikan dengan rasio leverage yang digunakan untuk mengukur perbandingan total hutang terhadap total asset yang dimiliki perusahaan (Nugroho, 2012:31), sehingga dapat dirumuskan sebagai berikut :

$$
\text { Leverage }=\frac{\text { Total Hutang }}{\text { Total Asset }}
$$

3. Firm Size (Ukuran Perusahaan)

Ukuran perusahaan menggambarkan besar kecilnya perusahaan yang ditunjukkan oleh total asset, jumlah penjualan dan kapitalisasi pasar (Azlina, 2010:356). Untuk melakukan pengukuran terhadap ukuran perusahaan, total asset dapat menggambarkan ukuran perusahaan, semakin besar aset maka 
semakin besar perusahaan tersebut (Deviyanti dan Sudana, 2018:1424). Pengukuran terhadap ukuran perusahaan yang diukur berdasarkan total asset menggunakan logaritma natural dari total aktiva (Indra, 2016:33), dirumuskan sebagai berikut :

\section{Ukuran Perusahaan $=$ LnTotal Asset}

4. Earning Management (Manajemen Laba)

Manajemen laba merupakan upaya manajer mengintervensi informasi dalam laporan keuangan dengan tujuan mengelabui stakeholder yang ingin mengetahui kinerja dan kondisi perusahaan (Sulistyanto, 2018:6). Untuk mengukur manajemen laba, peneliti menggunakan pendekatan discretionary accrual menggunakan Modified Jones Model yang dapat mendeteksi manajemen laba lebih baik dibandingkan model lainnya (Sulistyanto, 2018:225). Model perhitungannya adalah sebagai berikut :

a. Menghitung Total Accrual

Keterangan :

$$
\mathrm{TA}_{\text {it }}=\mathrm{NI}_{\mathrm{it}}-\mathrm{CFO}_{\mathrm{it}}
$$

$\mathrm{TA}_{\mathrm{it}} \quad$ : Total Accrual perusahaan i pada periode $\mathrm{t}$

$\mathrm{NI}_{\mathrm{it}} \quad$ : Net Income perusahaan i pada periode $\mathrm{t}$

$\mathrm{CFO}_{\text {it }} \quad$ : Cash Flow from Operating perusahaan i pada periode $\mathrm{t}$

b. Menghitung Nondiscretionary Accrual

$\mathrm{NDA}_{i t}=\mathbf{a 1}\left(1 / A_{i t-1}\right)+a 2\left(\left(a R E V_{i t}-a R E C_{i t}\right) / A_{i t-1}\right)+a 3\left(P_{P E} / A_{i t-1}\right)+\epsilon$

Keterangan :

$\mathrm{NDA}_{\mathrm{it}}$ : Nondiscretionary Accrual pada tahun $\mathrm{t}$

a : fitted coefficient yang diperoleh dari hasil regresi pada perhitungan total accrual

$\mathrm{A}_{\mathrm{it}-1} \quad$ : Total asset pada periode $\mathrm{t}$

$\mathrm{aREV}_{\text {it }}$ : Revenue perusahaan i pada periode $\mathrm{t}$

$\mathrm{aREC}_{\mathrm{it}}$ : Receivable perusahaan i pada periode $\mathrm{t}$

$\mathrm{PPE}_{\mathrm{it}} \quad$ : Property Plant and Equipment perusahaan i pada periode $\mathrm{t}$

$\epsilon \quad$ : Error

c. Menghitung Discretionary Accrual

Keterangan :

$$
\mathbf{D A}_{\mathrm{it}}=\left(\mathbf{T} \mathbf{a}_{\mathrm{it}} / \mathbf{A}_{\mathrm{it}-1}\right)-\mathbf{N D A _ { i t }}
$$

$\mathrm{DA}_{\mathrm{it}} \quad$ : Discretionary Accrual perusahaan pada periode $\mathrm{t}$

$\mathrm{TA}_{\mathrm{it}} \quad$ : Total Accrual perusahaan i pada periode $\mathrm{t}$

$\mathrm{A}_{\mathrm{it}-1} \quad$ : Total asset pada periode $\mathrm{t}$

$\mathrm{NDA}_{\mathrm{it}} \quad$ : Nondiscretionary Accrual pada tahun $\mathrm{t}$

\section{Teknik Analisis Data}

Teknik analisis data menggunakan SPSS Ver. 20. Model analisis data menggunakan model regresi linier berganda dengan persamaan sebagai berikut : 
Keterangan :

$$
\mathrm{DA}_{\mathrm{it}}=\beta 0+\beta 1 \mathrm{~KB}+\beta \mathrm{LEV}+\beta \mathrm{SIZE}+\epsilon
$$

$\mathrm{DA}_{\mathrm{it}} \quad$ : Nilai discretionaryaccrual perusahaan pada periode $\mathrm{t}$

$\beta 1 \mathrm{~KB}$ : Kompensasi bonus perusahaan pada periode $\mathrm{t}$

$\beta$ LEV : Perjanjian hutang dengan proksi leverage perusahaan pada periode $t$

$\beta$ SIZE : Ukuran perusahaan pada periode $\mathrm{t}$

$\epsilon \quad$ : Error

\section{HASIL PENELITIAN DAN PEMBAHASAN}

\section{Deskripsi Data}

Penelitian ini menggunakan sampel perusahaan manufaktur sektor industri barang konsumsi yang terdaftar di Bursa Efek Indonesia (BEI) tahun 2016-2018 yang dipilih menggunakan metode purposive sampling. Berdasarkan kriteria yang telah ditetapkan, maka diperoleh sampel sebanyak 20 data perusahaan dengan jumlah observasi sebanyak 60 data perusahaan selama periode 2016-2018.

\section{Statistik Deskriptif}

Tabel 1. Analisis Statistik Deskriptif

\begin{tabular}{|l|r|r|r|r|r|}
\hline & \multicolumn{1}{|c|}{ N } & Minimum & \multicolumn{1}{c|}{ Maximum } & \multicolumn{1}{c|}{ Mean } & Std. Deviation \\
\hline KB & 60 & 0 & 1 &, 55 &, 502 \\
LEV & 60 &, 077 & 1,155 &, 33661 &, 183333 \\
SIZE & 60 & 14,910 & 30,529 & 23,20906 & 5,812724 \\
EARNING & 60 &,- 206 &, 263 &, 02209 &, 072989 \\
Valid N (listwise) & 60 & & & & \\
\hline
\end{tabular}

Tabel 1. berisi nilai minimum (terendah), maksimum (tertinggi), mean (ratarata) dan standar deviasi untuk masing-masing variabel yang diteliti pada penelitian ini. Penjelasan mengenai tabel di atas adalah sebagai berikut :

1. Menunjukkan bahwa $\mathrm{N}$ merupakan jumlah data yang digunakan menjadi sampel dalam penelitian ini yaitu sebanyak 60 data perusahaan.

2. Variabel kompensasi bonus (KB) memiliki nilai mean sebesar 0,55 dengan standar deviasi sebesar 0,502. Nilai terkecil 0 dan nilai terbesar 1 . Nilai 0 artinya perusahaan tidak melakukan pemberian bonus dan nilai 1 artinya perusahaan melakukan pemberian bonus.

3. Variabel debt covenant (LEV) memiliki nilai terkecil sebesar 0,077 dan nilai terbesar sebesar 1,155. Nilai mean sebesar 0,33661 atau 33\% dengan standar deviasi sebesar 0,183333 . Hal ini berarti bahwa rata-rata perusahaan sampel memiliki hutang sebesar 0,33661 atau 33\% dari total aset yang dimiliki oleh 
perusahaan. Nilai debt covenant diatas angka $>0,05$ menunjukkan bahwa total aset yang dimiliki perusahaan lebih banyak menggunakan hutang sebagai sumber pendanaan perusahaan.

4. Variabel firm size (SIZE) memiliki nilai mean sebesar 23,20906 dengan standar deviasi sebesar 5,812724. Nilai terkecil sebesar 14,910 dan nilai terbesar sebesar 30,529. nilai minimum dan maximum dari variabel perusahaan diukur berdasarkan total aset yang dimiliki perusahaan.

5. Variabel earning management (EARNING) memiliki mean sebesar 0,02209 dengan standar deviasi sebesar 0,072989. Nilai terkecil sebesar $-0,206$ dan nilai terbesar sebesar 0,263. pada nilai terkecil sebesar $-0,206$. Koefisien bernilai negatif berarti perusahaan terindikasi melakukan income descreasing atau menurunkan laba, dan untuk nilai tertinggi sebesar 0,263 dengan koefisien bernilai positif yang berarti perusahaan terindikasi melakukan income increasing atau menaikkan laba.

\section{Analisis Data}

\section{Uji Normalitas}

Uji normalitas yang dilakukan dengan menggunakan metode uji kolmogorov-smirnov menghasilkan nilai kolmogorov-smirnov sebesar 0,797 dan tidak signifikan pada 0,549 yang berada diatas nilai residu 0,05. Hal ini berarti $\mathrm{H}_{0}$ diterima yang berarti bahwa data residual berdistribusi normal dan model regresi layak untuk dipakai dalam penelitian. Berikut hasil uji normalitas dengan menggunakan kolmogorov-smirnov.

Tabel 2. One-Sample Kolmogorov-Smirnov Test

\begin{tabular}{|ll|r|}
\hline & & $\begin{array}{r}\text { Unstandardized } \\
\text { Residual }\end{array}$ \\
\hline $\mathrm{N}$ & Mean & 60 \\
Normal Parameters & $0 \mathrm{E}-7$ \\
& Std. Deviation &, 05566076 \\
Most Extreme Differences & Absolute &, 103 \\
& Positive &, 042 \\
Kolmogorov-Smirnov Z & Negative &,- 103 \\
Asymp. Sig. (2-tailed) & &, 797 \\
\hline
\end{tabular}
a. Test distribution is Normal.
b. Calculated from data. 


\section{Uji Multikolinearitas}

Tabel 3. Uji Multikolinearitas

\begin{tabular}{|c|c|c|c|c|c|c|c|}
\hline \multirow[t]{2}{*}{ Model } & \multicolumn{2}{|c|}{$\begin{array}{c}\text { Unstandardized } \\
\text { Coefficients }\end{array}$} & \multirow{2}{*}{$\begin{array}{c}\text { Standardized } \\
\text { Coefficients } \\
\text { Beta } \\
\end{array}$} & \multirow[t]{2}{*}{$\mathrm{T}$} & \multirow[t]{2}{*}{ Sig. } & \multicolumn{2}{|c|}{$\begin{array}{c}\text { Collinearity } \\
\text { Statistics } \\
\end{array}$} \\
\hline & B & Std. Error & & & & Tolerance & VIF \\
\hline (Constant) & ,065 & ,036 & & 1,820 & ,074 & & \\
\hline KB & ,075 & ,015 &, 518 & 4,985 & ,006 & ,960 & 1,042 \\
\hline LEV & ,115 & ,041 & ,288 & 2,776 & ,007 & ,962 & 1,039 \\
\hline SIZE &,- 002 & ,001 &,- 136 & $-1,334$ & 187 & ,997 & 1,003 \\
\hline
\end{tabular}

a. Dependent Variable: EARNING

Berdasarkan hasil pengujian multikolinearitas pada tabel 3 di atas, diketahui bahwa variabel kompensasi bonus (KB) memiliki nilai tolerance sebesar 0,960 dan nilai VIF sebesar 1,042. Variabel debt covenant (LEV) memiliki nilai tolerance sebesar 0,962 dan nilai VIF sebesar 1,039. Dan variabel firm size (SIZE) memiliki nilai tolerance sebesar 0,997 dan nilai VIF sebesar 1,003. Pada masing-masing variabel yang terlihat pada tabel menunjukkan bahwa nilai VIF kurang dari 10 dan nilai tolerance lebih dari 0,1 . Sehingga dapat disimpulkan bahwa tidak terjadi multikolinearitas dalam model regresi.

\section{Uji Heteroskedastisitas}

Tabel 4. Uji Glejser

Coefficients $^{\mathrm{a}}$

\begin{tabular}{|c|c|c|c|c|c|c|}
\hline & \multirow[t]{2}{*}{ Model } & \multicolumn{2}{|c|}{$\begin{array}{l}\text { Unstandardized } \\
\text { Coefficients }\end{array}$} & $\begin{array}{l}\text { Standardized } \\
\text { Coefficients }\end{array}$ & \multirow[t]{2}{*}{$\mathrm{T}$} & \multirow[t]{2}{*}{ Sig. } \\
\hline & & $B$ & Std. Error & Beta & & \\
\hline \multirow{4}{*}{1} & (Constant) & 043 & ,023 & & 1,843 & 071 \\
\hline & $\mathrm{KB}$ & ,001 & 010 & ,014 & 105 & 917 \\
\hline & LEV & ,027 & ,027 & ,136 & 1,007 & 318 \\
\hline & SIZE & ,000 & ,001 &,- 072 &,- 543 & ,590 \\
\hline
\end{tabular}

a. Dependent Variable: RES2

Berdasarkan tabel 4 di atas, dapat dilihat nilai signifikan probabilitas dari semua variabel independen berada di atas 0,05 yaitu sebesar 0,917 untuk variabel kompensasi bonus, 0,318 untuk variabel debt covenant, dan 0,590 untuk variabel firm size. Sehingga dapat disimpulkan bahwa dalam model regresi tidak mengandung heteroskedastisitas. 
Tabel 5. Analisis Regresi Linier Berganda

\begin{tabular}{|c|c|c|c|c|c|}
\hline \multirow[t]{2}{*}{ Model } & \multicolumn{2}{|c|}{$\begin{array}{l}\text { Unstandardized } \\
\text { Coefficients }\end{array}$} & \multirow{2}{*}{$\begin{array}{c}\text { Standardized } \\
\text { Coefficients }\end{array}$} & \multirow[t]{2}{*}{ T } & \multirow[t]{2}{*}{ Sig. } \\
\hline & $B$ & Std. Error & & & \\
\hline (Constant) & ,065 & , 036 & & 1,820 & , 074 \\
\hline KB & ,075 & ,015 & (518 & 4,985 & , 006 \\
\hline LEV & 115 & , 041 & 288 & 2,776 & ,007 \\
\hline SIZE &,- 002 & 001 &,- 136 & $-1,334$ & , 187 \\
\hline
\end{tabular}

Berdasarkan tabel 5. di atas, maka diperoleh persamaan regresi linier berganda sebagai berikut :

$$
\text { EARNING }=0,065+0,075 \mathrm{~KB}+0,115 \mathrm{LEV}-0,002 \mathrm{SIZE}+0,036
$$

Tabel 6. Uji Koefisien Determinasi

\begin{tabular}{|c|c|r|r|r|}
\hline Model & $\mathrm{R}$ & $\mathrm{R}$ Square & $\begin{array}{c}\text { Adjusted R } \\
\text { Square }\end{array}$ & $\begin{array}{c}\text { Std. Error of the } \\
\text { Estimate }\end{array}$ \\
\hline 1 &, $647^{\mathrm{a}}$ &, 418 &, 387 &, 057132 \\
\hline
\end{tabular}

a. Predictors: (Constant), SIZE, LEV, KB

b. Dependent Variable: EARNING

Berdasarkan tabel 6. di atas, menunjukkan nilai $\mathrm{R}^{2}$ sebesar 0,418 dengan nilai adjusted $\mathrm{R}^{2}$ sebesar 0,387 artinya praktek manajemen laba dijelaskan oleh kompensasi bonus, debt covenant dan firm size hanya 38,7\% sedangkan 61,3\% dijelaskan oleh faktor-faktor lain diluar model yang dianalisis.

\section{Uji Parsial (Uji Statistik t)}

\section{Tabel 7. Uji Statistik T Coefficients $^{\mathrm{a}}$}

\begin{tabular}{|c|c|c|c|c|c|c|}
\hline & \multirow[t]{2}{*}{ Model } & \multicolumn{2}{|c|}{$\begin{array}{l}\text { Unstandardized } \\
\text { Coefficients }\end{array}$} & \multirow{2}{*}{$\begin{array}{c}\text { Standardized } \\
\text { Coefficients }\end{array}$} & \multirow[t]{2}{*}{$\mathrm{T}$} & \multirow[t]{2}{*}{ Sig. } \\
\hline & & $B$ & Std. Error & & & \\
\hline \multirow{4}{*}{1} & (Constant) & ,065 & ,036 & & 1,820 & ,074 \\
\hline & $\mathrm{KB}$ & ,075 & ,015 & ,518 & 4,985 & ,006 \\
\hline & LEV & ,115 & ,041 & ,288 & 2,776 & ,007 \\
\hline & SIZE &,- 002 & ,001 &,- 136 & $-1,334$ & ,187 \\
\hline
\end{tabular}

a. Dependent Variable: EARNING

Berdasarkan jumlah variabel dalam penelitian ini, didapatkan $t_{\text {tabel }}$ dengan rumus $\mathrm{df}=\mathrm{n}-\mathrm{k}=60-3=57$, maka di dapatkan $\mathrm{t}_{\text {tabel }}$ sebesar 2,002. Dengan demikian dapat dijelaskan sebagai berikut : 
1. Berdasarkan uji $\mathrm{t}$ yang dilakukan, diperoleh nilai $\mathrm{t}_{\text {hitung }}$ pada variabel kompensasi bonus (KB) sebesar 4,985 sehingga $t_{\text {hitung }}$ lebih besar dari $t_{\text {tabel }}$ $(4,985>2,002)$ dan nilai signifikan probabilitas sebesar 0,006 lebih kecil dari $0,05(0,006<0,05)$. Sehingga dapat disimpulkan bahwa variabel kompensasi bonus berpengaruh positif terhadap earning management.

2. Berdasarkan uji t pada variabel debt covenant (LEV) diperoleh nilai $t_{\text {hitung }}$ sebesar 2,776 lebih besar dari $t_{\text {tabel }}$ sebesar 2,002 $(2,776>2,002)$ dan nilai signifikan probabilitas sebesar 0,007 lebih kecil dari $0,05(0,007<0,05)$. Sehingga dapat disimpulkan bahwa variabel debt covenant berpengaruh positif terhadap earning management.

3. Berdasarkan uji t pada variabel firm size (SIZE) diperoleh nilai $t_{\text {hitung }}$ sebesar -1,334 lebih kecil dari $t_{\text {tabel }}$ sebesar 2,002 $(-1,334<2,002)$ dan nilai signifikan probabilitas sebesar 0,187 lebih besar sari $0,05(0,187>0,05)$. Sehingga dapat disimpulkan bahwa variabel firm size tidak berpengaruh positif terhadap earning management.

\section{Uji Simultan (Uji Statistik F)}

\section{Tabel 8. Uji Statistik F ANOVA $^{\text {a }}$}

\begin{tabular}{|l|r|r|r|c|c|}
\hline \multicolumn{1}{|c|}{ Model } & Sum of Squares & Df & Mean Square & F & Sig. \\
\hline \multirow{4}{*}{$\begin{array}{l}\text { Regression } \\
\text { Residual }\end{array}$} &, 132 & 3 &, 044 & 13,432 &, $001^{\mathrm{b}}$ \\
Total &, 183 & 56 &, 003 & & \\
\hline
\end{tabular}

a. Dependent Variable: EARNING

b. Predictors: (Constant), SIZE, DEBT, BONUS

Berdasarkan jumlah variabel dan data sampel pada penelitian, didapatkan $\mathrm{f}_{\text {tabel }}$ dengan rumus :

df $(\mathrm{n} 1)=\mathrm{k}-1=3-1=2$

df $(n 2)=n-k=60-3=57$, maka di dapatkan $f_{\text {tabel }}$ sebesar 3,159.

Sehingga berdasarkan tabel 4.8. di atas dapat dijelaskan bahwa hasil uji menunjukkan nilai $f_{\text {hitung }}$ sebesar 13,432 lebih besar dari $f_{\text {tabel }}$ sebesar 3,159 $(13,432>3,159)$ dengan nilai signifikan probabilitas sebesar 0,001 lebih kecil dari $0,05(0,001<0,05)$. Sehingga dapat disimpulakan bahwa terdapat adanya pengaruh kompensasi bonus, debt covenant dan firm size terhadap earning management secara bersama-sama. 


\section{PENUTUP}

\section{Kesimpulan}

Berdasarkan hasil pengujian dan analisis dalam penelitian ini, maka dapat ditarik kesimpulan sebagai berikut :

1. Kompensasi bonus berpengaruh signifikan terhadap earning management pada perusahaan manufaktur yang terdaftar di Bursa Efek Indonesia tahun 2016-2018.

2. Debt covenant berpengaruh signifikan terhadap earning management pada perusahaan manufaktur yang terdaftar di Bursa Efek Indonesia tahun 20162018.

3. Firm size tidak berpengaruh signifikan terhadap earning management pada perusahaan manufaktur yang terdaftar di Bursa Efek Indonesia tahun 20162018.

4. Kompensasi bonus, debt covenant, dan firm size berpengaruh signifikan secara bersama-sama terhadap earning management pada perusahaan manufaktur yang terdaftar di Bursa Efek Indonesia tahun 2016-2018.

\section{Saran}

Berdasarkan kesimpulan yang telah disampaikan di atas, maka penulis dapat mengemukakan saran sebagai berikut :

1. Disarankan bagi investor agar lebih memperhatikan dan mempertimbangkan berbagai faktor yang dapat mempengaruhi pengambilan keputusan dalam berinvestasi maupun permberian pinjaman.

2. Bagi perusahaan disarankan agar melakukan pengawasan internal atas kinerja manajemen untuk meminimalisir kemungkinan terjadinya penyimpangan yang dapat merugikan perusahaan maupun stakeholder.

3. Bagi peneliti selanjutnya disarankan untuk dapat mencari ataupun menambah faktor-faktor lain yang dapat mengakibatkan pengaruh terhadap earning management selain variabel yang telah diteliti dalam penelitian ini.

4. Untuk memperoleh hasil penelitian yang maksimal sesuai dengan yang diharapkan, sebaiknya menambah jumlah sampel yang akan diteliti dan memperpanjang periode penelitian.

\section{DAFTAR PUSTAKA}

Agustia, Dian. 2013. Pengaruh Faktor Good Corporate Governance, Free Cash Flow dan Leverage Terhadap Earning management. Jurnal Akuntansi dan Keuangan Vol. 15, No. 1, Mei 2013, (hal 27-42).

Azlina, Nur. 2010. Analisis Faktor yang Mempengaruhi Manajemen Laba. Pekbis Jurnal, Vol.2, No.3, November 2010:355-356. 
Deviyanti, N. W. T., dan Sudana, I. P. 2018. Pengaruh Bonus, Ukuran Perusahaan dan Leverage pada Manajemen Laba. e-journal Akuntasi, Vol. $23.2 \mathrm{Mei}$ (2018): 1415-1441. Fakultaas Ekonomi dan Bisnis Unversitas Udayana.

Eddy., Lili Syafitri., dan Trisnadi Wijaya. 2014. Analisis Pengaruh Struktur Kepemilikan, Good Corporate Governance dan Ukuran Perusahaan Terhadap Manajemen Laba Perusahaan Manufaktur yang Terdaftar di BEI.

Elfira, Anisa. 2014. Pengaruh Kompensasi Bonus Dan Leverage Terhadap Manajemen Laba. Jurnal Akuntansi Vol. 2 No. 2. Universitas Negeri Padang.

Fatmariani. 2013. Pengaruh Struktur Kepemilikan, Debt Covenant dan Growth Opportunities Terhadap Konservatisme Akuntansi Pada Perusahaan Manufaktur yang Terdaftar di BEI.

Gunawan, I. K., Ari Surya, D. N., dan Ayu Purnamawati, I, G. 2015. Pengaruh Ukuran Perusahaan, profitabilitas, dan Leverage Terhadap Earning Management Pada Perusahaan Manufaktur di BEI. e-Jurnal.Vol. 03, No.01.

Herawati, Nurul., dan Zaki Baridwan. 2007. Manajeman Laba Pada Perusahaan Yang Melanggar Perjanjian Hutang.Symposium Nasional Akuntansi X.

Indra, Rendy. 2016. Pengaruh Kompensasi Bonus, Debt Covenant, Firm size terhadap Manajemen Laba.Universitas Pendidikan Bandung.

Jensen, M. C., and Meckling, W. H. 1976. Theory of the Firm : Managerial Behavior, Agency Costs and Ownership Structure. Journal of Financial Economics, Oktober, 1976, V. 3, No. 4, pp. 305-360.

Kusumawardani, N. F., dan R. Rosiyana Dewi. 2016. Motivasi Bonus, Pajak dan Utang Dalam Tindakan Manajemen Laba. Media Riset Akuntansi, Auditing \& Informasi Vol.16, No.1 April 2016. Universitas Trisakti.

Nugroho, D. A. 2012. Pengaruh Struktur Kepemilikan Manajerial, Debt Covenant, Tingkat Kesulitan Keuangan Perusahaan, dan Risiko Litigasi Terhadap Konservatisme Akuntansi. Universitas Diponegoro Semarang.

Palestin, H. S. 2008. Analisis Pengaruh Struktur Kepemilikan, Praktik Corporate Governance dan Kompensasi Bonus Terhadap Manajemen Laba.

Pambudi, J. E. 2017. Pengaruh Kepemilikan Manajerial dan Debt Covenant Terhadap Konservatisme Akuntansi. Competitive, Vol.1, No.1, Januari-Juni 2017.

Prasetyo, W. S. 2011. Pengaruh Corporate Governance, Bonus Plans, Debt Covenant dan Firm Size Terhadap Manajemen Laba. Universitas Diponegoro Semarang.

IAI (Ikatan Akuntan Indonesia).2013.ED PSAK No. 1.Penyajian Laporan keuangan.

Pujiati, E. J., dan M. Arfan. 2013. Struktur Kepemilikan dan Kompensasi Bonus serta Pengaruhnya Terhadap Manajemen Laba pada Perusahaan Manufaktur yang Terdaftar di Bursa Efek Indonesia Tahun 2006-2010.Jurnal Telaah dan Riset Akuntansi.Vol.6.No. 2. Hlm. 122-139. Universitas Syiah Kuala.

Pujiningsih, A. I. 2011. Pengaruh Struktur Kepemilikan, Ukuran Perusahaan, Praktik Corporate Governance dan Kompensasi Bonus Terhadap Manajemen Laba. Jurnal Ekonomi dan Akuntansi. 
Randika, Rendi. 2012. Pengaruh Kompensasi Bonus, Leverage dan Ukuran Perusahaan Terhadap Praktek Manajemen Laba Pada Perusahaan yang Tergabung Dalam Indeks LQ 45 di BEI.

Rindengan, R. J. 2015. Pengaruh Bonus Plan dan Debt To Equity Terhadap Manajemen Laba. Politeknik Negeri Manado.

Setiawati, Lilis., dan Ainun Na`im. 2000.Manajemen Laba. Jurnal Ekonomi dan Bisnis Indonesia, Vol 15.

Sugiyono. 2014. Metode Penelitian Pendidikan Pendekatan Kuantitatif, Kualitatif dan $R \& D$. Bandung : Alfabeta.

Sulistyanto, Sri. 2018. Manajemen Laba Teori dan Model Empiris. Jakarta:Grasindo.

Tanomi, Rehobot. 2012. Pengaruh Kompensasi Manajemen, Perjanjian Hutang dan Pajak Terhadap Manajemen Laba Pada Perusahaan Manufaktur di Indonesia. Berkala Ilmiah Mahasiswa Akuntansi - Vol. 1, No.3. 30-35. Mei 2012.

Undang-Undang No. 20 Tahun 2008

Widowati, Maduretno. 2013. Pengaruh Corporate Governance, Bonus Plans dan Firm Size Terhadap Manajemen Laba. Fokus Ekonomi. Vol. 8 No.1. Juni 2013: 39-51.

Widyaningdyah, Agnes Utari. 2001. Analisis Faktor-faktor Yang Berpengaruh Terhadap Earning Management Pada Perusahaan Go Public Di Indonesia. Jurnal Akuntansi \& Keuangan.Vol.3, No.2. November 2001 :89-101.

Wijaya, V. A., dan Christiawan, Y. J. 2014. Pengaruh Kompensasi Bonus, Leverage dan Pajak Terhadap Earning Management Pada Perusahaan yang Terdaftar di BEI. Tax \& Accounting Review, Vol.4, No.1, 2014.

Www.idx.co.id

Yulia, Mona. 2013. Pengaruh Ukuran Perusahaan, Profitabilitas, Financial Leverage dan Nilai Saham Terhadap Perataan Laba Pada Perusahaan Manufaktur, Keuangan dan Pertambangan di BEI. Universitas Negeri Padang.

Yulivia, Y,. Resti Y. M,. Dan Popi. 2015. Kepemilikan Institusional, Kepemilikan Publik, Kompensasi Bonus dan Leverage Terhadap Manajemen Laba.

Yupita, Vina., Sri Fadilah., dan Helliana. 2017. Pengaruh Bonus Plans, Debt To Equity, dan Political Cost Terhadap Manajemen Laba. ISSN: 2460-6561. Vol.3, No.2, 2017. 